\section{Ethical Lingua}

Journal of Language Teaching and Literature

ISSN 2355-3448 (Print)

ISSN 2540-9190 (Online)

Volume 5, Number 1, February 2018 pp. $16-30$

\title{
How Do Junior High School Students Utilize Interactional Strategies in Speaking Activity?
}

\author{
Hidayatul Avia ${ }^{1} \&$ Yuli Astutik ${ }^{* 2}$ \\ *yuliastutik@umsida.ac.id \\ 1,2 Universitas Muhammadiyah Sidoarjo, Indonesia \\ Received : 22 January 2018; Accepted : 14 February 2018 \\ DOI : : https://doi.org/10.30605/ethicallingua.v5i1.757
}

\begin{abstract}
Interactional strategies are very important especially for English as a foreign language learners which can help the learners negotiate of the meaning during the interaction in speaking activity. The aim of this research is to analyze the interactional strategies (ISs) utilized by three students at different levels (Low, Average, High) in speaking activity at the eighth grade students of SMP Islam As-Sakinah Sidoarjo. This research uses qualitative descriptive as a research design, which all of the data are obtained through observation and interview for three students at different level such as low level learner ( $L L L)$, average level learner (ALL) and high level learner (HLL). In brief, the results of this research show that LLL uses all aspects of interactional strategies in her speaking activity, average level learner (ALL) uses some aspects of interactional strategies and high level learner (HLL) almost never use the aspects of interactional strategies in his speaking activities.
\end{abstract}

Keywords: learning strategies; interactional strategies; speaking 


\section{Introduction}

Speaking is an activity for representing the thought and use all of the organ speech of the language user to produce the utterances for communicating with other people. The rule of speaking is to shape the language as usage and connect to the realization of language as use in spoken interaction as talking (Widdowson, 1978, p. 59). Therefore, the students of junior high school in Indonesia should master this skill well. It is because the graduate of junior high school has expected to use English appropriately in real communication which should have well fluency and accuracy. Discussing about English as a subject at junior high school in Indonesia, certainly it is related to the teaching and learning process of English class. There are so many experts have explained how to teach English well like teaching method, technique and strategies. However, in this research, the researchers are going to discuss more about the students' side especially in English learning strategies, especially in speaking skill.

According to Oxford (1990, p. 8) learning strategies is described as approach in particular communicative competence which is employed by the learners to learn and solve the difficulty in language learning. It means that learning strategies can help the learners manage, direct, determine and guide their language learning process. There are some learning strategies that can be used by the students to make learners easier, for example Oxford (1990, p. 147) mentions there are three groups of indirect strategies that are metacognitive, affective and social strategies.

One of the important things that should be paid attention in speaking activity is social strategies, it is important for the students because this strategy is connected to the strategy of self-monitoring which can help the students correct and give attention to their own difficulties (Oxford, 1999, p. 170). Social strategy is known as communication strategies which can help the student negotiate the meaning during the interaction. According to Goh and Burns (2012, p. 63) the ability of person to use strategies fittingly to maintain an interaction going is a reflection of language learners' strategic competence. It means that as much as the language learners are able to convey the message well, it depends on how the language learners can keep the interaction and handle the problems occur in the communication. During the oral communication, the students should pay attention to pragmatic aspects of communication which help the students negotiate meaning between various participants, this is called interactional strategies.

Interactional strategies are similar to discourse strategies which are included exemplification, confirmation checks, comprehension checks, repetition, clarification requests, repetition checks, exemplification requests and assistance appeal (Goh \& Burn, 2012, p. 66). These strategies are useful communication 
strategies which aids for the learners to find other ways of expressing their meaning, to clarify or repeat what has been said to make sure that the massage is delivered well and understandable for the listener. This interactional strategy is also a way to overcome students' anxiety in speaking. In her research, Astutik (2017) found that low learners who use more interactional strategies are more confidence in performing their speaking than those who did not.

From preliminary research, the researchers found that some students tried to speak in English though they got difficulties to find an appropriate vocabularies to say. They tend to repeat the words, tried to ask clarification when they did not understand about their friends' comment and so forth. On the other hand, other students seem to relax when the teacher asked them to speak in English, even they were very confidence though their English speaking ability was not very good. In Fact, the students in this school have already used Interactional Strategies (ISs) in their learning of English speaking.

Based on those explanations, the researchers want to analyze more how the learning strategies especially ISs proposed by Goh and Burn used by eighth grade students at SMP Islam As-Sakinah Sidoarjo. Then, the formulation that can be used in this research are: 1) to what extent does low level learner at the eighth grade student at SPM Islam As-Sakinah Sidoarjo use ISs in speaking activity?, 2) to what extent does average level learner at the eighth grade student at SPM Islam As-Sakinah Sidoarjo use ISs in speaking activity?, 3) to what extent does high level learner at the eighth grade student at SPM Islam As-Sakinah Sidoarjo use ISs in speaking activity?

\section{Method}

In this research, the researchers used qualitative descriptive as the research design because the data was described based on a real situation or phenomenon which happened in the activity. This research took place in SMP Islam As-Sakinah Sidoarjo especially at the eighth grade students. This school was chosen based on the approach applied in this grade where in the English learning the students were forced to communicate with others, it aids students to increase their English especially in speaking activity. English lesson is taught twice in a week for each classes. The class provided with LCD projector, AC, white board, pictures, laptop and audio to support the learning process.

To determine the subjects, the researchers used purposive sampling because descriptive qualitative is about choosing the subject which is judged to be typical or representative of the population. Then, to categorize the subject into three levels (low, average and high) the researchers used the students score from middle test in the same semester. Low level learner (LLL) is student who has a rank score 16-42, average level learner (ALL) is student who has a rank score 43-72 and for the highest level learner (HLL) is students who has a a 
rank score 73-99. Each category consists of one learner who join speaking activity in English subject.

To collect the data the researchers employed two kinds of instrument, such as: Observation and Interview. The researchers used non participant observation and they did not include in the classroom activity. The researchers only sat inside the classroom and took a note about the interactional strategies based on Goh and Burn's theory such as exemplification, confirmation checks, comprehension check, repetition, clarification requests, repetition requests, exemplification requests, assistance appeal. Besides, the researchers also used video recorder to catch every single of the students' activity, according to Battacherjee (as cited in Wulandari, 2016, p. 25) it is commonly a good idea to electronically record interviews for future reference. Interview was also used in collecting the data, the researchers did face-to-face interview with the subject that chosen by giving unstructured and generally open-ended questions to find out the subjects opinion and to validate the observation data.

The data were analyzed by using interactional strategies proposed by Goh and Burns. The purpose of using ISs learning strategies was to find out the types of strategies utilized by three different levels of the eighth grade students in their speaking, to know the dominant form of ISs and to know the students' responses during the implementation of ISs in their speaking activity in English subject. The data gained were analyzed through some steps: first, the recorded data were transcribed, then transcribing was analyzed through identification by using the framework adapted from Goh and Burns (2012, p. 63) to analyze how a low learner, average learner and high learner use interactional strategies in their speaking activities. The data analysis was carried out through sorting out similar information, categorizing information and interpreting the data from observation and interview and answer research questions.

\section{Results \& Discussion}

The researchers described the interactional strategies (ISs) used by low level learner, average level learner and high level learner to learn English in speaking activity at the eighth grade students of SMP Islam As-Sakinah Sidoarjo and students' response toward of interactional strategies that are used by low level learner, average level learner and high level learner to learn English in speaking activity at eighth grade of SMP Islam As-Sakinah Sidoarjo.

The first and the second meetings were conducted on Thursday, 12th January 2017 and Saturday, 14th January 2017. It was held in 8th-B. There were thirty six students at the class. For every meeting the teacher decided the students into a group discussion and gave them a topic. A group discussion consisted of 5 students. The teacher placed the three subject into the same group. For the first meeting the group was discussed about "adjective and comparative" 
and the second meeting the teacher gave a lesson about "superlative and equal". The time allotment was $2 \times 45$ minutes, the class began at $09.00 \mathrm{am}$. In pre-speaking activity, the teacher greeted the students then checked the attendance list to make sure that all of the students were present and checked the tidiness of the students' uniform. She asked the students to stand up while she checked. Then, she gave little bit ice breaker to build up students' concentration. Such as; "what is this?" (the teacher raises her hand), "hands" (students answer). "and this one is?" (she touches her nose), "nose" (students answer). "this one is?" (she touches her cheeks), "cheeks" (students answer). "and then?" (she touches her forehead) but some of students said "bathuk", "chin" and the teacher informed that bathuk is forehead, then the students followed her. "and then" (she touches eyes), "ayes" (students answer). After that the teacher asked the students to touch part of their body based on her instructed. The teacher said nose and the students touched her nose, she said ayes and they touched their eyes, she said cheeks and they touched their cheeks. She said head and they touched their head. Then, after all of the ice breaking and make sure that the students was focused and ready for researching, she asked the students to sit up and open their book. She asked the students to open page 150 and reviewed little bit about the last lesson which had been explain several days before. It was done to investigate how far their understanding.

Interactional strategies (ISs) are used by three students of SMP Islam As-Sakinah Sidoarjo who has different level, that are low level learner (LLL), average level learner (ALL), high level learner (HLL). The data of Interactional Strategies (ISs) used by three different level students of SMP Islam As-Sakinah Sidoarjo that are reflected in the total of ISs used low level learner (LLL), ISs used by average level learner (ALL) and ISs used by high level learner (HLL).

\section{Interactional Strategies Used by Low Level Learner}

Interactional Strategies (ISs) are used by low level learner on the discussion of adjective, comparative degree, superlative degree and equal in the 1stand 2nd meeting of English lesson. The results of ISs used by LLL can be seen from the table below:

Table 1. ISs used by low level learner (LLL)

\begin{tabular}{|c|c|c|c|}
\hline \multirow[b]{2}{*}{ Interactional Strategies } & \multicolumn{2}{|c|}{ Frequency } & \multirow[b]{2}{*}{ Explanation of Interview } \\
\hline & $1^{\text {st }}$ & $2^{\text {nd }}$ & \\
\hline $\begin{array}{l}\text { 1. Exemplification : } \\
\text { Offering an example } \\
\text { to make one's point } \\
\text { clear. }\end{array}$ & 0 & $\sqrt{ }$ & $\begin{array}{l}\text { LLL offers an example oftentimes to } \\
\text { the listeners, because of LLL is hard } \\
\text { to convey and make point clear in her } \\
\text { message. }\end{array}$ \\
\hline
\end{tabular}




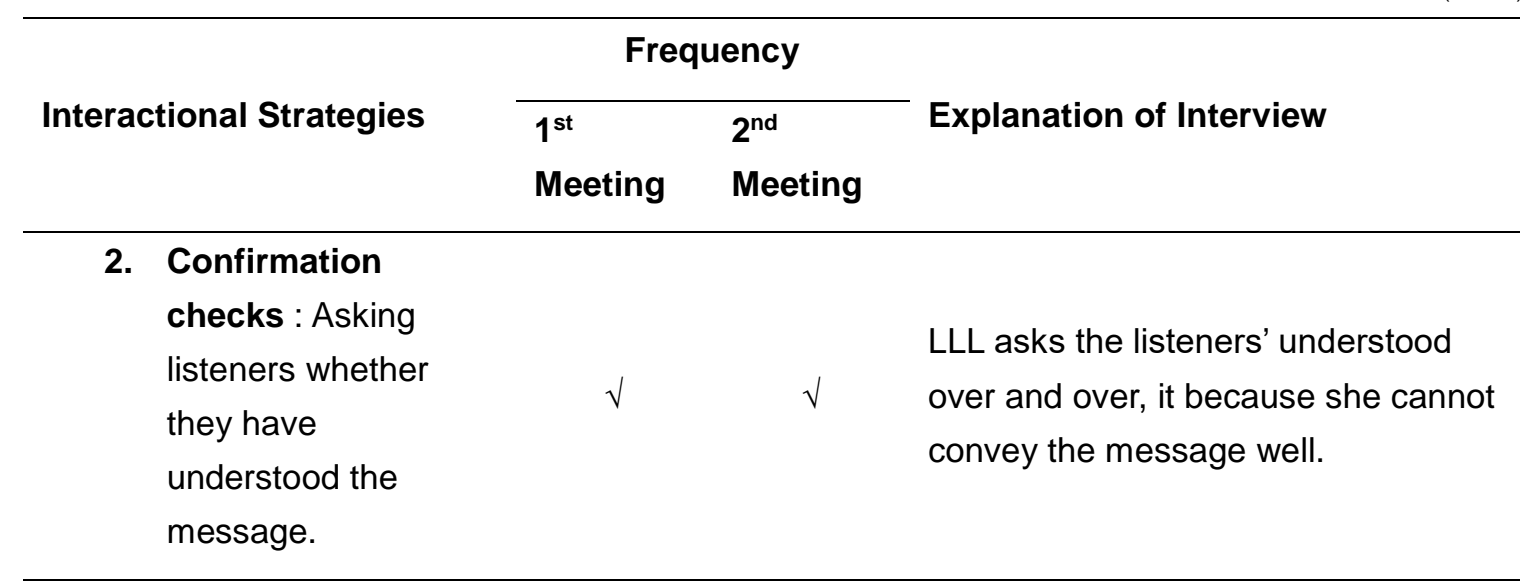

\section{Comprehension} checks :

Paraphrasing what is heard to confirm one's understanding.
LLL paraphrases and uses simple word often to help her to confirm one's understanding.

\section{Repetition :}

Repeating all or part of what is said to

$\sqrt{ } \quad \sqrt{ }$

LLL oftentimes repeats some parts of check one's own what she said to check her own understanding. understanding.

\section{Clarification} request : Asking the speaker to explain a point further.
LLL asks to the speaker to explain again what the speaker said, it because the LLL has difficulty to get the point of the message.

\section{Repetition request :}

Asking the speaker to say something again.
LLL asks the speaker to repeat what the speaker said oftentimes.

\section{Exemplification}

\section{Request:}

Asking the speaker to give an example.
LLL asks the speaker to give a very simple example to help her more understand with the speaker says.

\section{Assistance Appeal :}

Asking the listener for help with difficult words.
LLL asks to the listeners for help the difficult words oftentimes it because the LLL has limited vocabularies so that she has difficulty to convey the message fluency. 
Avia \& Astutik:

How Do Junior High School Students Utilize Interactional Strategies in Speaking Activity?

Table 1 explains that LLL used all of ISs during the discussion. It draws that LLL utilized all aspects of ISs proposed by Goh and Burns between in 1st meeting and 2nd meeting except aspect exemplification in 1st meeting.

Here, the example illustrates how LLL used exemplification strategies of ISs when the teacher asked to her about the subject lesson.

1)

Teacher: "How about you Fatimah (LLL), what do you know about adjective?"

LLL: $\quad$ (quit) ...... "Adjective hhhmmm adjective is .... Sesuatu yang mengenai person."

Teacher: "Ok, good. Adjective are words to describe or modify others words which are used to identify or quantify individual people and unique things."

2)

Teacher: "Ok, now we know what means of adjective. And we have learned some of adjectives. Now, I ask to you (LLL) to give me example simple sentence using adjective."

"Saya minta kamu untuk memberikan contoh kalimat sederhana menggunakan kata sifat."

LLL: "ee... apa ya ustadzah... the pink girl...ehmm... the pink girl good. ee... no.. no.. the pink girl beautiful."

Teacher: "The pink girl is beautiful.

"Ok, good."

Quotation 1) and 2) were gotten from the whole recording of teaching-learning process in 1st meeting and 2nd meeting of English lesson. From those quotations the researchers found aspect of exemplification of ISs used by LLL in 2nd meeting only and aspect of confirmation checks in 1st and 2nd meeting. It indicated that she is not conveyed the message well because of she doesn't understand and confuse with the message that she has said. Furthermore, LLL used the aspect of comprehension checks of ISs also in 1st and 2nd meeting.

3)

LLL: "Apa yaa.. My hel..ehm... My helm (for helmet) is..."

"Your helm (for helmet) is better than mine."

From those quotation 3) exhibited that LLL used comprehension checks of ISs in 1st and 2nd meeting under the lesson of comparative degree, it indicates that she wanted to say "helmet" but she utilized an Indonesian which is commonly the same as semantically with the target language of "helm". 
The aspect of repetition was found also by LLL both in 1st and 2nd meeting.

4)

LLL : : "My mother cooks fast eeh... bukan... itu..apa sorry dengan cepat bahasa inggrisnya apa... quick ya."

"My mother cooks quick than usual."

"Eehh..quickly.. My mother cooks quickly than usual."

The quotation 4) the LLL repeats some parts of what she said for several times to check her own understanding. That is indicated that she has difficulty to convey her message well because of she hard to understand with what she has said. It was found in the 1 st and 2 nd meeting under the lesson of comparative degree.

5)

Teacher: "And then, superlatives give me one example, raise your hands."

"Raise your hands, anyone?"

"Ok, no one wants to raise your hand."

"Ok, I will directly choose one of you."

"I want you Fatimah to give me an example of superlative degree."

LLL: "Saya ustadzah?"

"Ustadzah want me to give example superlative?"

Those conversation showed that LLL asks to the speaker to explain again what the speaker said, it because the LLL has difficulty to get the point of the message that speaker said.

6)

Teacher: "Ok now look at the picture on the LCD."

"Based on the picture there are some pictures that have same quantity."

"For the example: apples are as many as oranges."

"Is it correct Fatimah?"

LLL: What ustadzah?" (quit)

"Repeat again, Us."

Teacher: "Apples are as many as oranges."

"Based on the picture is that correct Fatimah? Bahwa apel sama banyaknya dengan jeruk?"

LLL: "Yes, Ustadzah that is correct"

"Apel sama..eeh sorry apples are as many as oranges...." 
Avia \& Astutik:

How Do Junior High School Students Utilize Interactional Strategies in Speaking Activity?

The quotation 6) is exhibited that PLL used repetition request of ISs which is supported by Goh and Burns' taxonomy. It is explained that LLL asked to her teacher as the speaker to repeat what the speaker said oftentimes to make her understood. Besides, LLL also used exemplification request in the 1st and 2nd meeting. Here, the example illustrates how LLL used exemplification request of ISs.

7)

LLL: $\quad$ When the teacher explains the lesson of differences of comparative and superlative degree and the teacher asks to her to give example both of it but the LLL is only quit..).

"eehhmm..sorry, Us I don't understand... ee.. Can you give one example first?"

"After that.. I give example." (LLL asks the speaker to give an example).

It showed that LLL asks the speaker to give a very simple example to help her understand about the speaker says. In addition, the LLL used the last ISs also during the learning process to help her in the interaction that is assistance appeal. The LLL utilized it when she got difficulty to express what has in her mind.

8)

LLL: "Putri is good friend..eeh.. apa itu lo.. yang terbaik. Sorry..best... ya.." (she asked her friend to look for the superlative vocabulary of good).

"Putri is the best... Putri is the best friend."

Teacher: "Putri, is the best friend of mine." (The teacher helped her to complete her message to make her sentence understandable more).

Those quotations explained that LLL got confuse for uttered the superlative vocabulary of good and she asked her friend to help her, it because the LLL has limited vocabularies so that she has difficulty to convey the message fluency. Other examples of assistance appeal of ISs that used by LLL in the 1st meeting, as the quotation follows:

9)

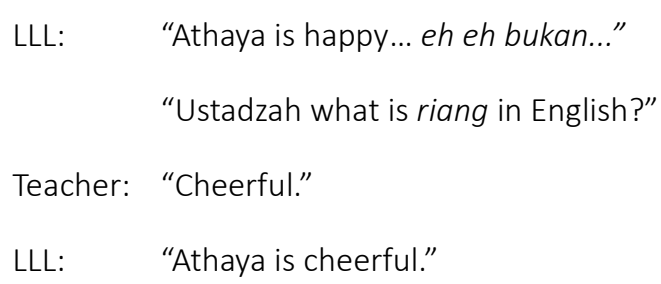

It exhibits that LLL has lack vocabulary which makes LLL difficult to convey her message fluency. Moreover, the result of the interview is corroborate that LLL oftentimes ask her friends to look for difficult words which is helped her to understand more and able to convey the message well. 


\section{Interactional Strategies Used by Average Level Learner}

Likewise as low level learner (LLL), the average level learner (ALL) also discussed the same topic as 1st and 2nd meeting of English lesson. The results of ISs used by ALL can be seen the following table:

Table 2. ISs used by Average Level Learner (ALL)

\begin{tabular}{|c|c|c|c|}
\hline \multirow{3}{*}{ Interactional Strategies } & \multicolumn{2}{|c|}{ Frequency } & \multirow{3}{*}{ Explanation of Interview } \\
\hline & $1^{\text {st }}$ & $2^{\text {nd }}$ & \\
\hline & Meeting & Meeting & \\
\hline $\begin{array}{l}\text { 1. Exemplification : } \\
\text { Offering an example to } \\
\text { make one's point clear. }\end{array}$ & $\sqrt{ }$ & $\sqrt{ }$ & $\begin{array}{l}\text { ALL seldom to offer an example to } \\
\text { make one's point clear, it because he } \\
\text { can convey his message clear enough } \\
\text { to the listeners. }\end{array}$ \\
\hline
\end{tabular}

2. Confirmation checks :

Asking listeners whether they have understood the message.

\section{Comprehension} checks : Paraphrasing what is heard to confirm one's understanding.
ALL rarely asks to the listeners whether they have understood or not about the message that he has delivered, it because ALL able to convey the message well enough.

4. Repetition :

Repeating all or part of what is said to check one's own ALL almost never doing paraphrased with what he was heard, it because ALL have good enough ability to catch up the message that the speaker said. understanding.

5. Clarification request : Asking the speaker to explain a point further.

ALL rarely repeats some parts of what he said to check his own understanding.

\section{Repetition request :} Asking the speaker to say something again.
ALL infrequently asks to the speaker to explain again what the speaker said, it because the ALL has good enough ability to catch up the message.

\section{Exemplification}

Request:

Asking the speaker to give an example.
ALL asks the speaker to repeat what the speaker said only for several times. 
How Do Junior High School Students Utilize Interactional Strategies in Speaking Activity?

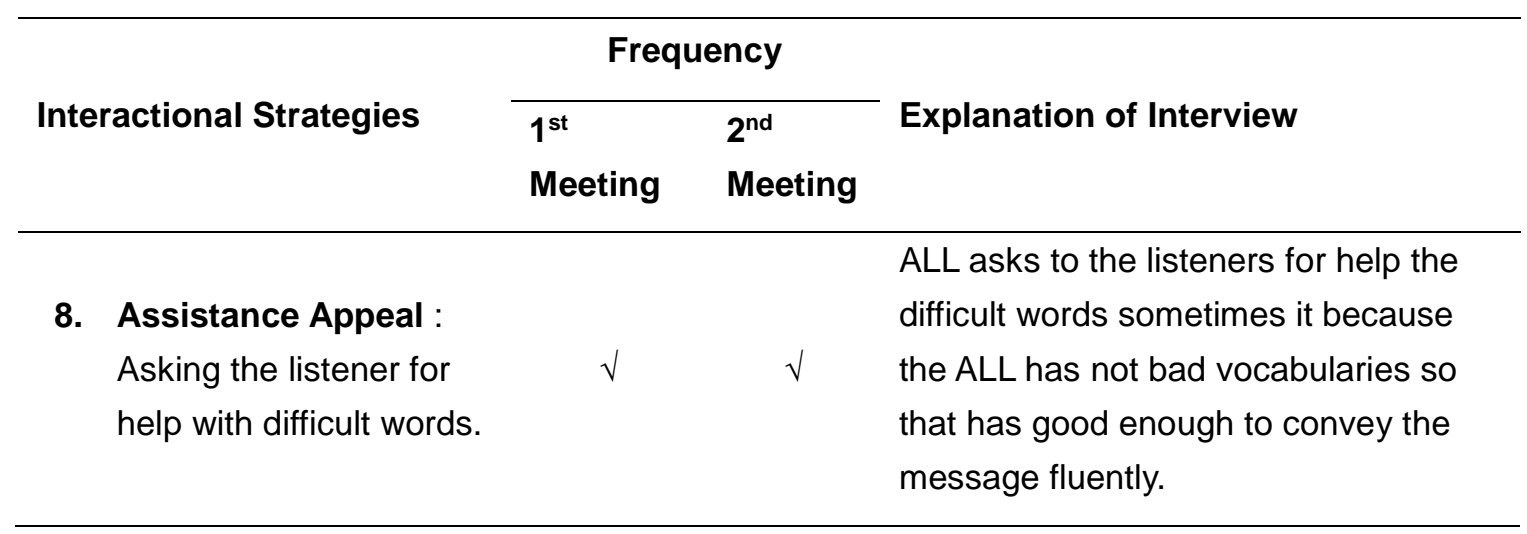

The result of research showed that ALL did not use whole the aspect of ISs. He used some aspects of ISs both in meeting 1 and meeting 2 except Confirmation checks, Comprehension checks and Clarification request. The following quotes illustrate of ISs that used by average level learner.

4)

Teacher: "Jamal... because you are the most unfocused today. So, please give me one example of comparative sentence."

ALL: $\quad$ "The window is bigger.... hhmm ee bukan - bukan... My home eeh.... My haus... my haus... oh I am Sorry Ustadzah... "My house.... is bigger than yours."

"Yaa I mean.... My house is bigger than yours."

Teacher: "Very good Jamal."

Based on the quotation above 4) it shows that ALL apparently used repetition of ISs in 1st meeting which is under the lesson of comparative degree. He repeated some parts of what he said rarely to check his own understanding, it is point out that ALL was able to convey his message but he little bit repeated his message to make his message understandable more. Besides, ALL used assistance appeal of ISs also to help him during the interaction. Here, the illustration of assistance appeals of ISs that used by AAL.

8)

ALL: $\quad$ "Example of equal ya ustadzah..... Finish the duty as... soon as.... Eehhmmm... as fast eehhh apa itu... sesegera mungkin.. faster ya?"

Friend: "Possible"

ALL: "Ya ya itu... possible."

"Finish the duty as soon as possible."

From those conversations 8) explains that ALL used assistance appeal in 2nd which is under the lesson about equal. ALL asked to the listeners for looking for the difficult words for several times it because ALL has not bad vocabularies so that he has good enough to convey the message fluently. 
Based on all of the finding of ISs aspect that used by ALL stated that ALL has good enough activity at speaking English and he has good interaction during the learning process of English lesson. Although he has little bit problem with his pronunciation, he could not express his opinion well but it did not decrease his motivation to speak up, he tried to develop his understanding of English to be an active participant during the learning process of English.

\section{Interactional Strategies Used by High Level Learner}

Unlike LLL and ALL who used many strategies in their communication, high level learner (HLL) used fewest of ISs that only used 2 ISs which is every point consist in low frequent. It is explained from the following table below:

Table 3. ISs used by High Level Learner (HLL)

\begin{tabular}{lll}
\hline \multirow{3}{*}{ Interactional Strategies } & \multicolumn{2}{c}{ Frequency } \\
\cline { 2 - 3 } & $1^{\text {st }}$ & $2^{\text {nd }}$ \\
& Meeting & Meeting
\end{tabular}

1. Exemplification :

Offering an example to 0

make one's point clear.
HLL once offers some examples to make his friends understand more with the example that he explained, it because he can convey his message well to the listeners.

HLL asks to the listeners whether they have understood or not about the message that he has delivered, it is only for make sure that his message that he said is delivered well.

\section{Comprehension}

checks : Paraphrasing

what is heard to confirm

one's understanding.
HLL have good ability to catch up the message that the speaker said.

4. Repetition :

Repeating all or part of what is said to check $0 \quad 0$ one's own understanding.

5. Clarification request :Asking the speaker to explain a point further.
HLL has good ability to catch up the main point of message that the speaker explained. 
Avia \& Astutik:

How Do Junior High School Students Utilize Interactional Strategies in Speaking Activity?

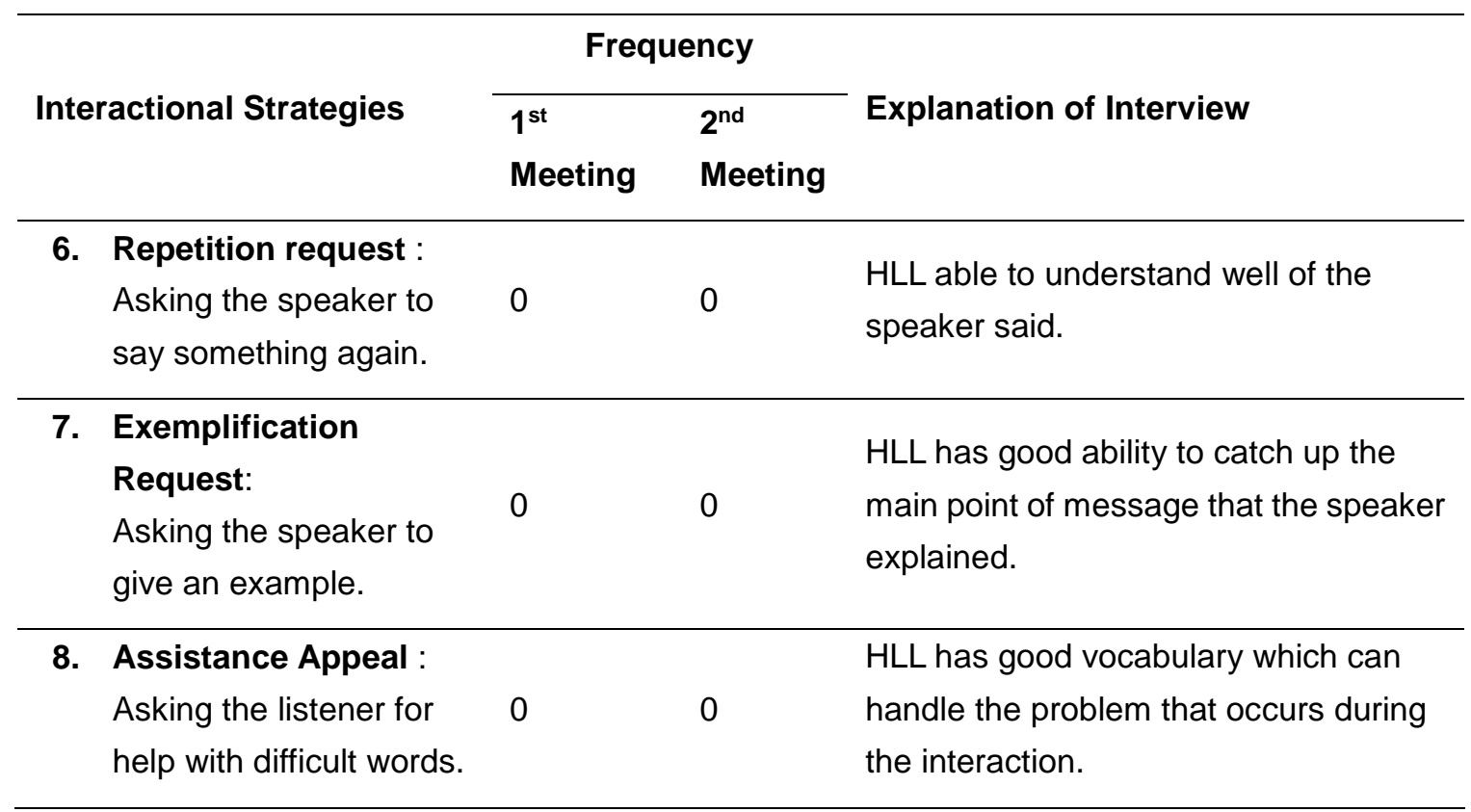

The table 3 shows that HLL only used a few aspects of interactional strategies which is every point consist in low frequent. He never used comprehension checks, repetition, clarification requests, repetition request, exemplification request and assistance appeal. He only used exemplification (1 times) and confirmation checks (1 times). It is proven that HLL has good ability in English. He has a lot of knowledge of vocabulary that can help his interaction during learning process. It is described from the following conversation below:

1)

Teacher: "That is our lesson today and we have to make story based on the picture."

"Could you give me an example sentence of equal?"

HLL: "As black as a bad."

"As playful as a Dewi."

From those quotes of the conversation HLL tried to give example based on the instruction that his teacher said while he looked at the picture. HLL was not only given an example but also give more than one example. It indicates that HLL has rich of vocabulary which is helpful to express his opinion. In addition, HLL used also confirmation checks, he used this aspect to check the listeners' understanding which is to make sure that what he has said is deliver well and understandable for his listeners. As illustrate of confirmation checks:

2)

HLL: "As strong as an elephant, I mean... the truck is strong as an elephant."

Teacher: "Is that correct?"

HLL: "The truck as strong as an elephant." 
HLL: "Ya. Fahmi is good job."

Based on all of the evidences above, it can be clarified that HLL has good speaking English which showed that he could give example appropriately with the teacher request. Then, he always has spirit to be active participant during the process learning which is supported by his statement in his interviewed that he liked speaking English because of it could be expended his knowledge. Even though, he did few mistakes in the second meeting when he was given an example of equal but he could handle it and enjoy the discussion.

The result from the interview indicated that HLL has good speaking English that is supported also by his value of his daily report, activity report and his middle test in the last semester. He has high value in every daily activity of English.

Overall, the results of this research concurred with research conducted by Astutik (2017) which stated that students with low speaking ability can speak when they using ISs strategies in speaking activities, especially in English class. Besides, they are also more confidence to speak up because with ISs strategies they have many ways to utter the word in English.

\section{Conclusion}

This research indicates that high level learner (HLL) tends not to use interactional strategies in his speaking activity. From interview shows that HLL is able to catch up the main point of message that the speaker explained. He also has a good English fluency than other students. He is very confidence and smart in the class. Meanwhile, average level learner (ALL) use almost all ISs in his speaking activity in English class. He can express his opinions although his pronunciation does not good enough. The interview data shows that ALL actually has a high interest in English but he has difficulty in pronouncing vocabulary in English. Low level learner (LLL) unexpectedly used all aspects of ISs in her speaking activity in English class. Although LLL does not have a good fluency in uttering English words and lack of vocabularies, but she tries to keep speaking when her teacher and friends communicate in English. Without realizing it, LLL is actually able to overcome her own problems. She often use repetition, clarification and ask for help to others when she gets difficulties in saying English words.

The result of this research implies that interactional strategies is a good way especially for students with low ability in speaking skill. For further researchers it is hoped that they can do the same research with different subjects and settings. 
How Do Junior High School Students Utilize Interactional Strategies in Speaking Activity?

\section{References}

Astutik, Y. (2017). Interactional Strategies Used by Low Level Learners in Public Speaking Class. JEES (Journal of English Educators Society), 2(2), 65-74.

Goh, C. M., and Burns, A. (2012). Teaching Speaking: A Holistic Approach. New York: Cambridge University Press.

Oxford, R. L. (1990). Language Learning Strategies. New York: Newbury House Publishers.

Widdowson. (1978). Teaching Language as Communication. Walton Street: Oxford University Press.

Wulandari, D. H. (2016). Learning Strategies Used By English Department Students in Learning Pronunciation. Unpublished Thesis: Universitas Negeri Surabaya, Surabaya. 